\title{
Potability Evaluation of Selected River Waters in Ebonyi State, Nigeria
}

\author{
J. I. Awu*, O. A. Ogunjirin, F. A. Willoughby, A. A. Adewumi \\ National Centre for Agricultural Mechanization, P.M.B. 1525, Ilorin, Nigeria.
}

\begin{abstract}
The study focused on the seasonal variation of physiochemical and microbial characteristics of three selected river water in Ebonyi State for human consumption. The three selected rivers studied were Iyioka, Idima and Ubei Rivers. Data were generated using Direct Reading Engineering method (DREM), Gravimetric method, Titrimetric method, Spectrophotometric method, Atomic Absorption Spectrophotometric method, and Total Viable count for physiochemical and microbiological analysis. The generated data was further subjected to statistical analysis using one way analysis of variance (ANOVA) on difference between means of parameters and graphical method to determine the spatial variation of the water quality characteristics. The time variations of the water quality characteristics as compared with the spatial variations showed that for some variables, there was statistical difference between the means of parameters with respect to time and space at various levels of significance. These include Phosphorus (5\%), Copper (1\%), Iron (5\%), Nickel (5\%), Cadmium (1\%), Salinity (1\%), Bacteria (1\%) for time variation; and Sulphate (1\%), Chemical Oxygen (5\%),Nickel (1\%), Arsenic (1\%), Zinc (1\%), Cadmium (1\%), Bacteria (1\%) for spatial variations during dry season and Chemical Oxygen (5\%), Nickel (1\%), for spatial variation during rainy season. Based on the World Health Organization and Standard Organization of Nigeria guidelines for drinking water, the results of microbial analysis also indicated that the selected river waters were polluted with disease causing microorganisms, such as E.Coliform, Salmonella, Bacillus Subtilis. Therefore, the river waters are not good for drinking. The consumers of water obtained from the three rivers are likely to suffer the following: typhoid, fever, intestinal problem, diarrhea, skin rash, cholera. Necessary recommendations such as treating the water with bio-sand filter before use, amongst others, were made.
\end{abstract}

KEYWORDS: water quality, physiochemical, microbia, spatial, river water, consumption, ANOVA

[Received November 20 2014; Revised January 212015 \& February 25 2015; Accepted May 10 2015]

\section{INTRODUCTION}

Water a universal solvent, the most widely distributed of all natural resources, is a "two edged knife", supporting life at one end and harboring disease causing germs and chemical contaminants at the other side (Otuu, 2011 ). Water contains physiochemical materials and microbial organisms which are generally unicellular organisms that are too small to be read or seen with the naked eye, but with the aid of microscope of high magnification. The various ways in which water promotes the economic and social wellbeing of a society are known as the beneficial uses of water (Otuu, 2011). These may be in form of water supply for domestic and industrial purposes, recreation and aquatic life. Unregulated waste disposal conflicts with use of the various water sources for a municipal needs. Laws had been developed to protect water quality for downstream uses in Nigeria.

On this note the establishment of river basin authorities and state water corporations was intended to regulate the use of water and the provision of potable water for beneficial uses (www.placng/lawsofnigeria/files/R9.pdf). Improving access to safe drinking water quality can result in tangible benefits to health; therefore every effort must be made to achieve a drinking water quality as safe as practicable (Olla, 2008).

All domestic, industrial and agricultural wastes affect in some way the normal life of water bodies and their influence is sufficient to render the water unacceptable for use when it is polluted (Okereke, 2006). Pollution of water body is the *Corresponding author's e-mail address: awujohnibe4uk@yahoo.com introduction of foreign bodies or increases in the concentrations of normal components of water body to such magnitudes that will upset the delicate eco-equilibrium of the water body and overpowering its natural cleansing power.

When these biotic and abiotic factors exist in optimal conditions, life in aquatic system is said to be balanced, and the water body will be colourless, odourless, tasteless, of neutral $\mathrm{pH}$, and a poor conductor of electricity. Pollution results in the alteration of these factors of stable eco-system so that the water becomes unacceptable for human and industrial uses (Westeot, 1976). Surface and ground water drawn from community supplies have a wide range of qualities. Although a few rivers may be adequate for public use without treatment, the majority of water sources must be processed to improve water quality to the level required for public use (Otuu 2011).

Generally variation in water quality depends on the source of the pollutants, time (season) and geogrphical location of the river. In the rainy season, the ground water movement is in continuous dilution resulting from increase rainfall making the physio-chemical and microbiological parameters of the river almost as good as that of fresh water. The primary purpose of any water quality variation evaluation is to determine the potentials of the parameters and any unwanted contaminants in the water body with respect to time and space. Contaminant in river waters includes human faeces, food remnants and a wide variety of organic and inorganic solid wastes and salts. A river is a major receptacle of all effluent discharges from 
domestic activities, depending on the location of the river and its tributaries. Consequently, a river environment is a site of tremendous microbial activities. The microbial distribution is associated with sunlight, temperature, oxygen levels and nutrient availability.

This study aims at:

- Analysing the water quality of Ubei, Idima and Iyioka rivers, all in south zone of Ebonyi State of Nigeria with respect to drinking.

- Establishing the concentrations or potentials of the different water quality parameters that can impact negatively or positively on consumers.

- Establishing time and spatial variations of the water quality parameters and to what level would these variations affect the quality of the waters.

\section{MATERIALS AND MethodS}

The area of study was southern zone of Ebonyi State of Nigeria. The study was carried out on three selected rivers, each with six distinct locations and about $5 \mathrm{~km}$ apart. The rivers and their test locations are:

a. Ubei Rivers, with test locations at: (i) Ubei Amaiyi River. (ii). Ubei Etiti River (iii) Ubei Amangwu River (iv) Ubei River Extension I (v) Ubei River Extension II (vi) Ubei River Extension III.

b. Idima Rivers, with test locations at: (i) Idima Okporojo River (ii) Idima Oko River (iii) Idima Amaiyi River (iv) Idima River Extension I (v) Ubei River Extension II (vi) Ubei River Extension III.

c. Iyioka Rivers, with test locations at: (i) Iyioka by Okwukwo River (ii) Iyioka River Extension I (iii) Iyioka River Extension II (v) Iyioka River Extension III (vi) Iyioka River Extension 1V.

Water samples were collected from the three different rivers. Tthe water samples were collected in January 2011 for dry season and June 2011 for rainy season. A total of eighteen (18) river locations data points were used. Each parameter test was replicated and an average was taken as the true value of the parameter. The samples collected were properly labelled and transferred to the pharmaceutics laboratory of the Department of Pharmaceutics, Uuniversity of Nigeria Nsukka for preservation and analysis. Some physical parameters were determined in-situ. The methods employed in the study are as described below.

Direct Reading Engineering Method (Drem): This was used mainly for the analysis of physical parameters such as total dissolved solid (TDS), pH, salinity, electrical conductivity (EC), dissolved oxygen, chemical oxygen and temperature. The Hacc Multimeter (model 150) was used to measure these parameters in situ.

Titrimetric Methods: This method deals with titrating the water sample with ethylene diamine tetra-acetic acid (EDTA) solution for water hardness (Otuu, 2011),

Spectrophotometeric Methods: This was used in the analysis of Nitrate (NO3), Carbonate $\left(\mathrm{CO}_{3}\right)$, Sulphate $\left(\mathrm{SO}_{4}\right)$, and Phosphate $\left(\mathrm{PO}_{4}\right)$. This method deals with the absorbance of light path length into the curvette which is directly proportional to the concentrations for a particular compound (Ajali, 2007).

Gravimetric Methods: The Total Suspended Solid (TSS) was determined by this method. A glass fiber was dried in oven at $100^{\circ} \mathrm{C}$ to obtain a known constant weight $\mathrm{W}_{1}$. A $50 \mathrm{ml}$ volume of each water sample taken at the same depth was filtered through fiber bed. The fiber was dried in a desiccator and weighed immediately to obtain the second weight $\mathrm{W}_{2}$. The total suspended solid concentration was calculated using the equation $\mathrm{TSS}=\left(\mathrm{W}_{2}-\mathrm{W}_{1}\right) / 50$

where: $\mathrm{W}_{2}=$ constant weight of solid on the fiber $(\mathrm{mg})$

$\mathrm{W}_{1}=$ weight of the empty dried glass fiber $(\mathrm{mg})$

$50=$ volume of water sample used $(\mathrm{ml})$

The total solid (TS) was obtained by calculating the arithmetic sum of the total dissolved solid (TDS) and the total suspended solid (TSS) as in eqn (1).

$$
\mathrm{TS}=\mathrm{TDS}+\mathrm{TSS}
$$

Turbidity was obtained directly from the total suspended solid (TSS), using the relationship

$$
\text { Turbidity = TSS/ } 50 \text { (Otuu, 2011) }
$$

Atomic Absorption Spectrophotometric Method: This was used in the determination of all the metallic elements such as Lead $(\mathrm{Pb})$, Copper $(\mathrm{Cu})$, Iron $(\mathrm{Fe})$, Nickel $(\mathrm{Ni})$, Magnesium $(\mathrm{Mg})$, Manganese (Mn), Arsenic (As), Zinc (Zn), Cadmium (cd) (Ajali, 2007).

Microbial Analysisi: For microbial analysis, the employed procedure includes the following:-

preparation of media; preparation of sterile petri-dish and oven-dried agar plate; and preparation of counting which includes dilution and counting.

For the purpose of biochemical test, a special growth media was employed for quicker identification. In this case some gram negative bacteria were grown on Macconkey agar so as to select coliform through cultural features. Their reactions to glucose and lactose determined the type of disease causing organism present.

The results of the analysis are tabulated and shown in the appendix for easy understanding of the variations of the river parameters with the help of descriptive compound line chart. The analysis was replicated to obtain the average value for each analysis. The generated data was further subjected to statistical analysis using one way analysis of variance (ANOVA) on difference between mean of parameter to determine their level of significant.

\section{RESULTS}

The behavioural pattern of the physical, chemical and microbiological parameter tests for the month of January and June using descriptive compound line chart are shown in Figures 1 to 25 in Appendix 1. The legend to the charts is presented in Table 1 in the same appendix. On the other hand, the summary of the Analysis of variance (ANOVA) test on physical, chemical and microbiological parameters with respect to time (season), space during dry season, and space during rainy season are shown in Table 2 in Appendix 2. 


\section{RESULTS DISCUSSION}

The results of this study show that there were significant differences in the mean values of some variables between time (dry and rainy season) and space at various levels of significance. With respect to time, the parameters with their levels of significant were: 5\% for Phosphate, $1 \%$ for Copper, $5 \%$ for Iron, $1 \%$ for Cadmium, $1 \%$ for Salinity, $1 \%$ Bacteria. However, with respect to space during dry season, the parameters levels of significant were: $1 \%$ for Sulphate, $5 \%$ for Chemical Oxygen, $1 \%$ for Nickel, $1 \%$ for Manganese, $1 \%$ for Arsenic, $1 \%$ for zinc and $1 \%$ for Bacterial. Also, comparing it with respect to space during rainy season, the parameters levels of significant were: $5 \%$ for Chemical Oxygen, $1 \%$ for Nickel and $1 \%$ for Manganese. But, other variables were not statistically different in their mean values within the period of study. Though, numerical difference may exist but statistical difference did not exist. This is because their F-Calculated (FCAL) was less than F-Tabulated (F-TAB).

On comparing the microbial river qualities of the three selected rivers studied to World Health Organization (WHO) and Standard Organization of Nigeria (SON) guidelines for drinking water. It was discovered that the three rivers are not good as drinking water sources because of the presence of some disease causing organisms such as E.coli, salmonella, bacillus subtilis. The possible pollutants of the river waters may be as a result of human activities in the upstream.

\section{CONCLUSION}

Iyioka River is the highest polluted river with Iyioka by Okwukwo as the highest polluted location. This is followed by Idima and Ubei rivers respectively. Generally it was found that there was continuous variation in the characteristics of all the rivers. Microbiologically the three selected rivers are not good for drinking because of the presence of bacteria and other disease causing organisms including fungi. The used of Bio-Sand filters together with water disinfectant amongst other methods are recommended for treating the water before human consumption.

\section{REFERENCES}

Abbasi, S. A. (1998): Water quality sampling and analysis, Discovery Publishing House, New Delhi-110002 India.

Administrative Map of Ebonyi State (1997): Published By Austino Tech. Service Nigeria. Architects Building Engineering and Cartographer, Ebonyi State, Nigeria.

Ajali, U. and S. I. Inya-Agha (2007): Spectroscopic Methods and Techniques for Life and Applied Science. First edition, Mason Production Ltd, Enugu State, Nigeria.

Armstrong F. A. J. (1963): Determination of nitrate in water by ultraviolet spectrophotometry. Anal. Chem., 35(9): 1292-1294.

Emmanuel O. O. (2006), Statistic for Agricultural and Biological Science. First edition, Cheston Agency Ltd. Enugu State, Nigeria.

McGuire M. J. and A. Obolensky (2002): Information collection rule Data analysis. Denver, Colorado: American water works association research foundation.

Okereke C. D. (2006): Environmental Pollution Control, First Edition. Barloz Publishers Inc. Owerri, Imo State, Nigeria.

Olla O. O. and I. E. Ahaneku (2008): Quality Evaluation of Various Water Sources in Ilorin. Journal of Agricultural Engineering and Technology (JAET), 16(2): 53-60.

Otuu F. C. (2011): Antimicrobial and Flocculant Properties of Moringa Oleifera Aqueous and Ethanolic Seed Extract in Some Hand Dug Well Water in Enugu State Metropolis. An unpublished paper presented for the award of Fellowship of Nigeria Institute of Science Laboratory Technology.

SON's and WHO's (2007). Guidelines for drinking water. available at (http://www.who.int/water_sanitaion_health/dwq/en/).

Westeot, D. W. (1976): Water quality for agriculture. Vikas Publishing House, New Delhi, FAO. Irrigation drainage paper No.29.

\section{APPENDIX 1}

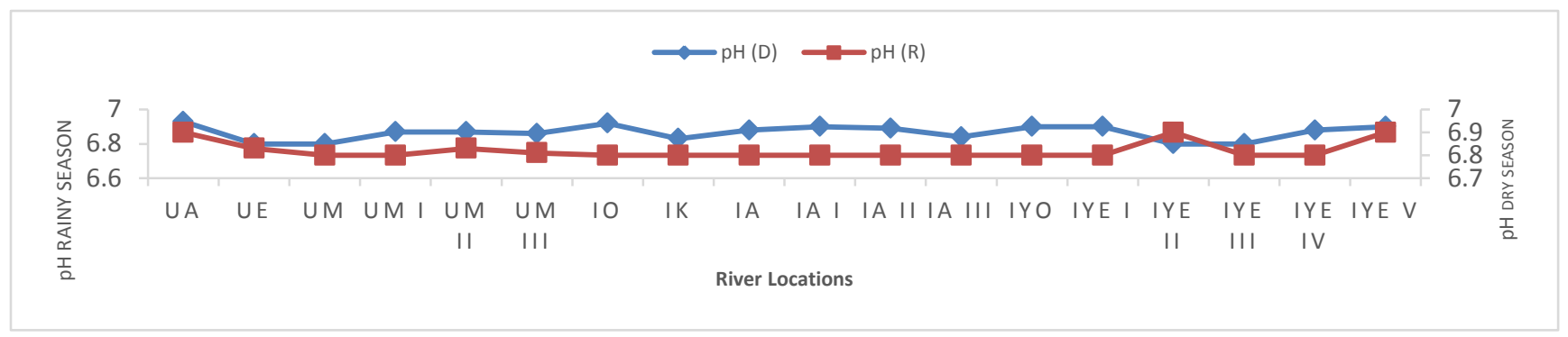

Figure 1: Behavioural pattern of $\mathrm{pH}$ with respect to time and space.

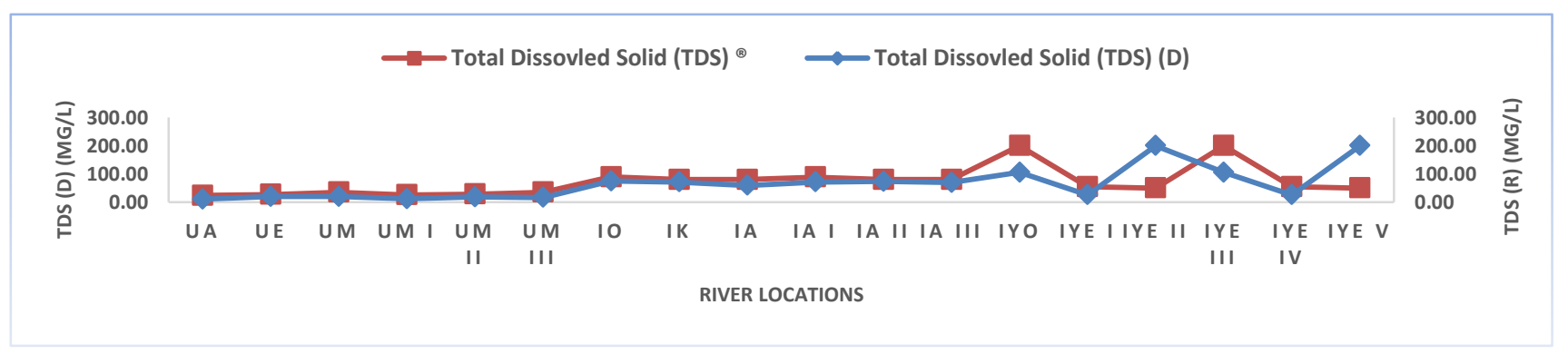

Figure 2: Behavioural pattern of Total Dissolved Solid with respect to time and space. 


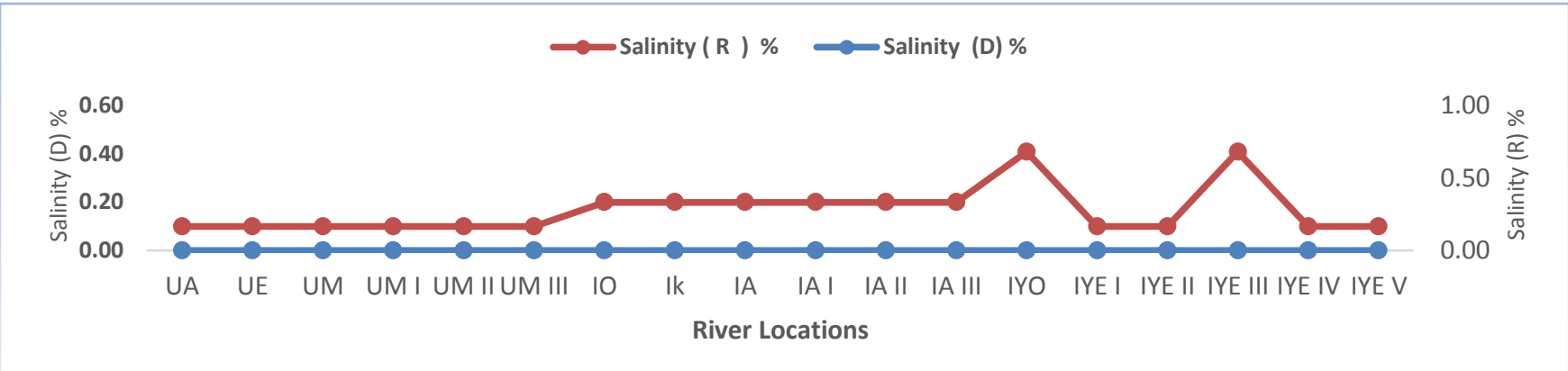

Figure 3: Behavioural pattern of Salinity with respect to time and space.

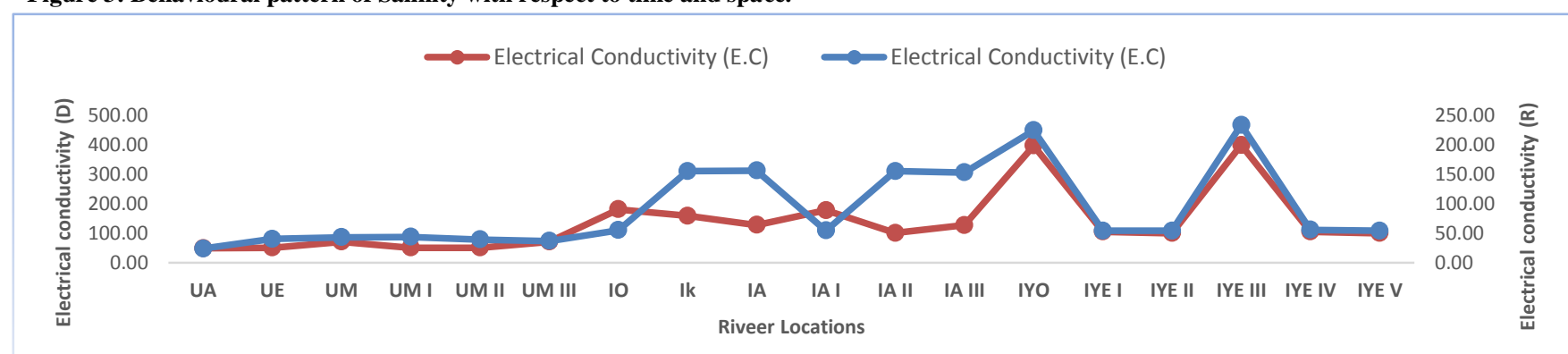

Figure 4: Behavioural pattern of Electrical Conductivity with respect to time and space.

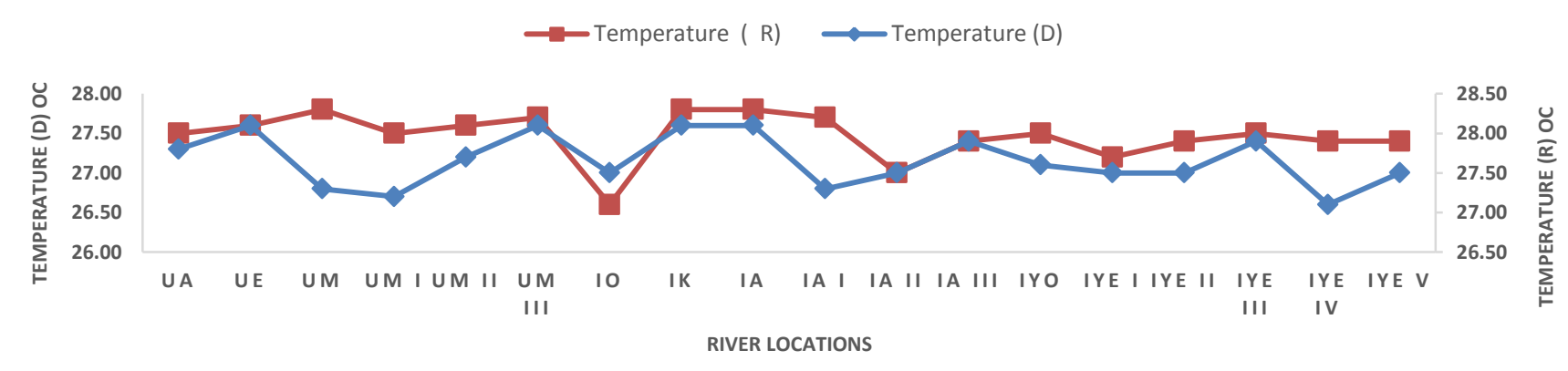

Figure 5: Behavioural pattern of Temperature with respect to time and space.

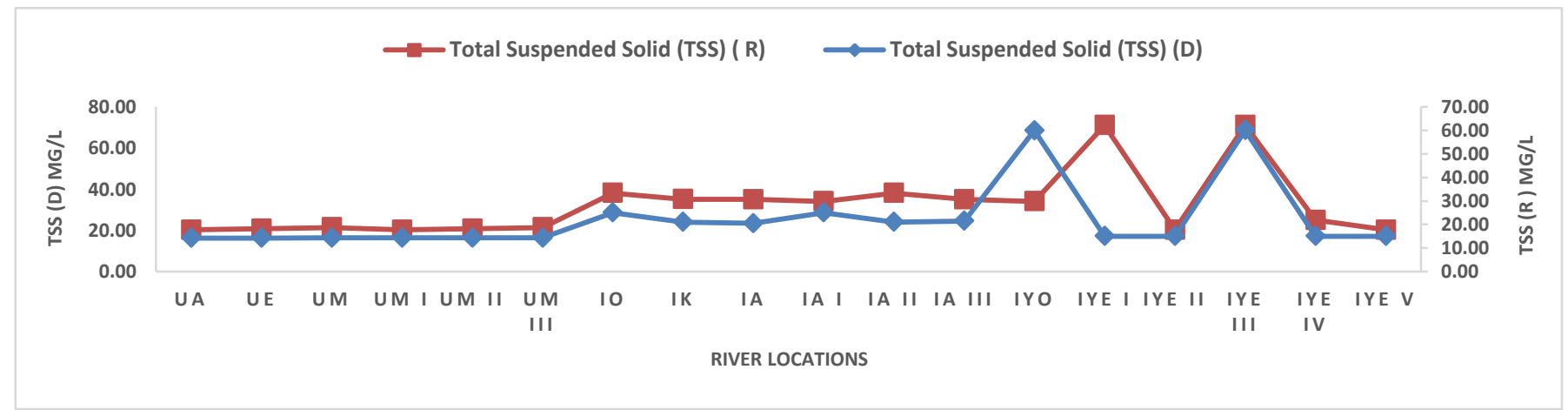

Figure 6: Behavioural pattern of Total Suspended Solid with respect to time and space.

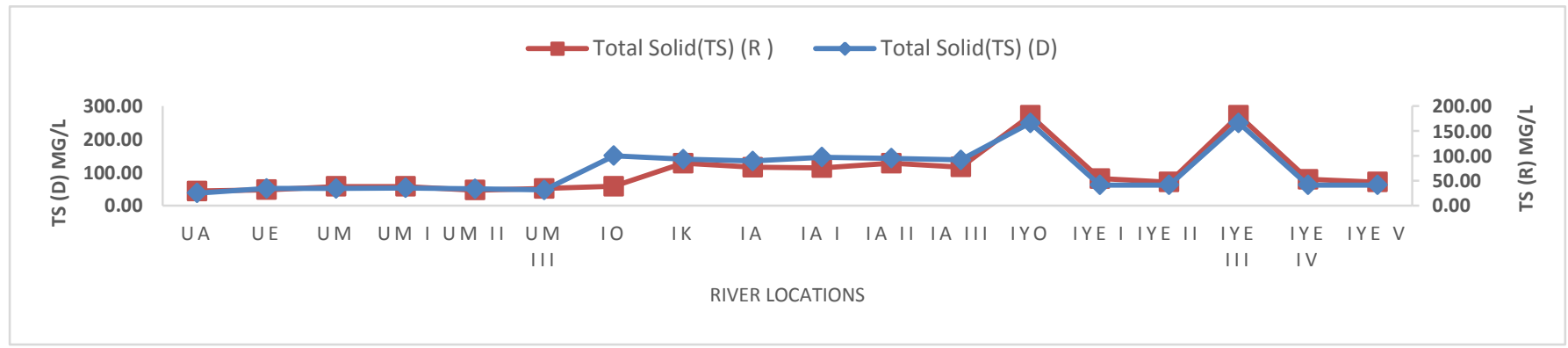

Figure 7: Behavioural pattern of Total Solid with respect to time and space. 


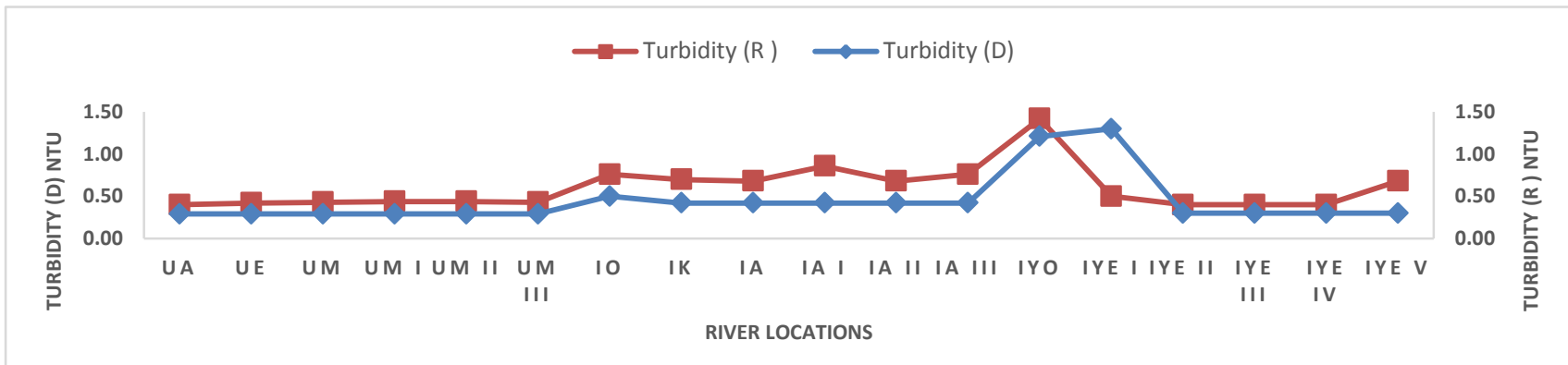

Figure 8: Behavioural pattern of Turbidity with respect to time and space.

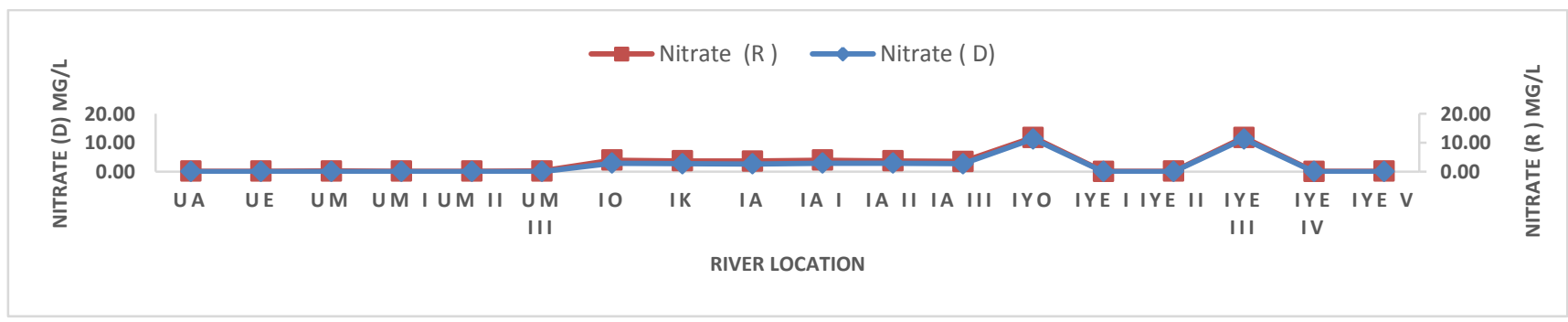

Figure 9: Behavioural pattern of Nitrate $\left(\mathrm{NO}_{3}\right)$ with respect to time and space.

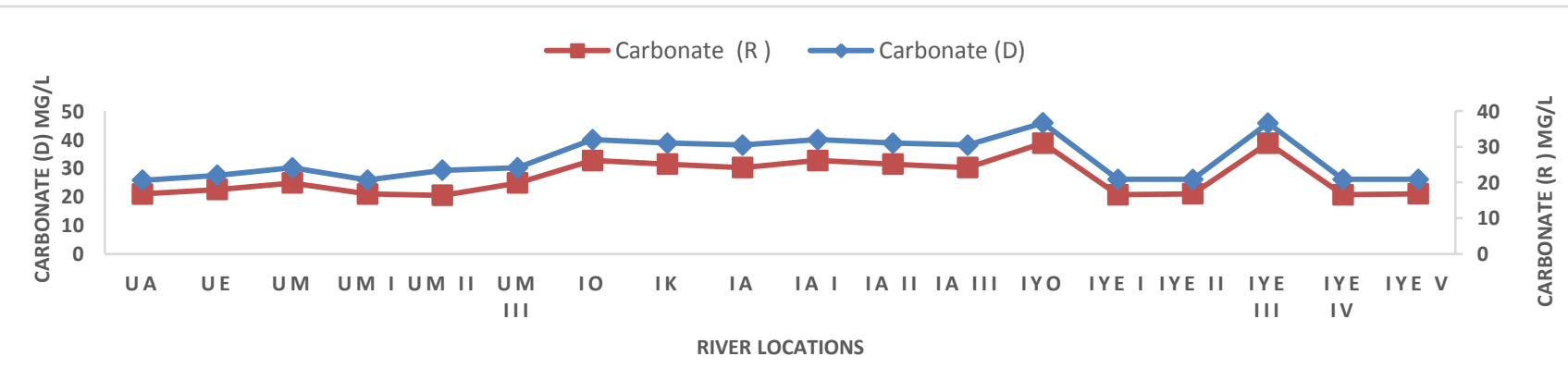

Figure 10: Behavioural pattern of Carbonate $\left(\mathrm{CO}_{3}\right)$ with respect to time and space.

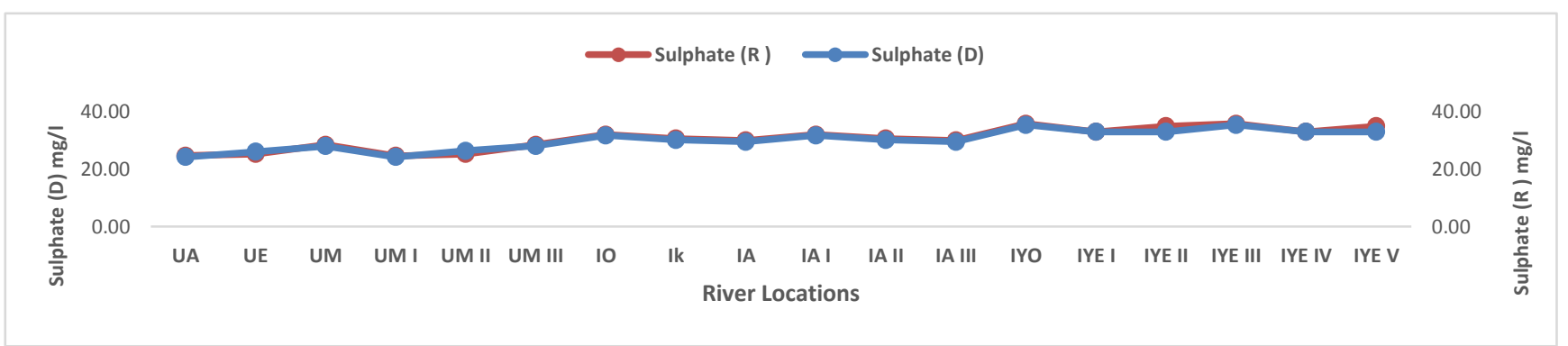

Figure 11: Behavioural pattern of Sulphate $\left(\mathrm{SO}_{4}\right)$ with respect to time and space.

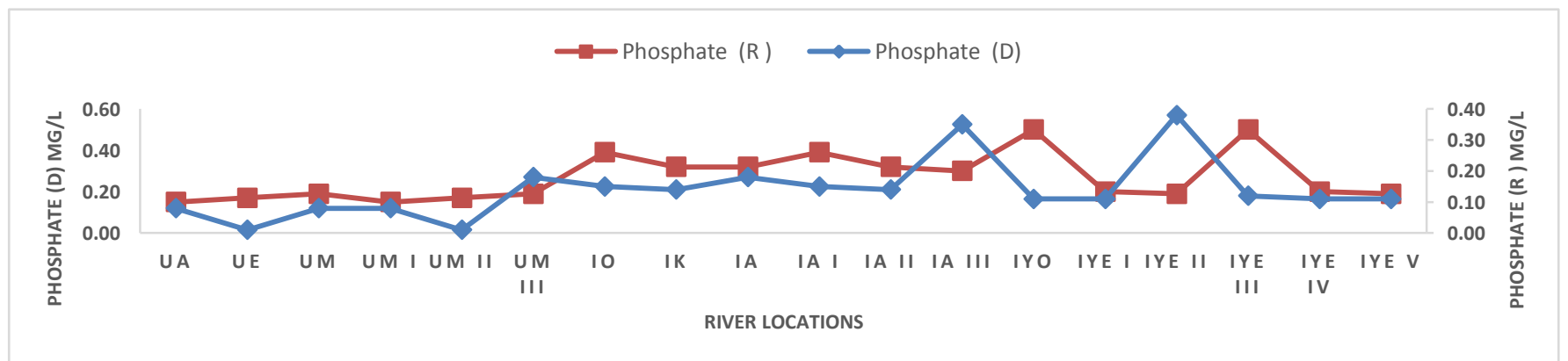

Figure 12: Behavioural pattern of Phosphate $\left(\mathrm{PO}_{4}\right)$ with respect to time and space. 


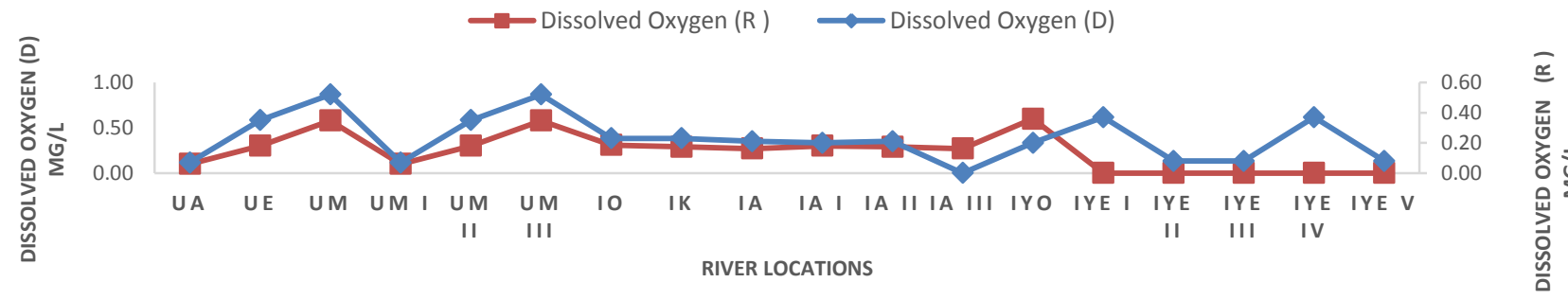

Figure 13: Behavioural pattern of Dissolved Oxygen with respect to time and space.

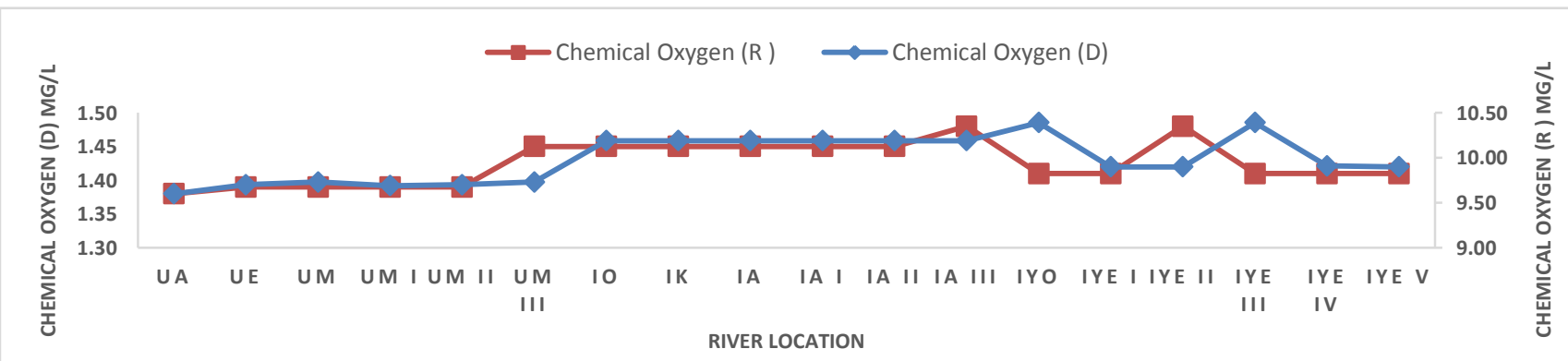

Figure 14: Behavioural pattern of Chemical Oxygen with respect to time and space.

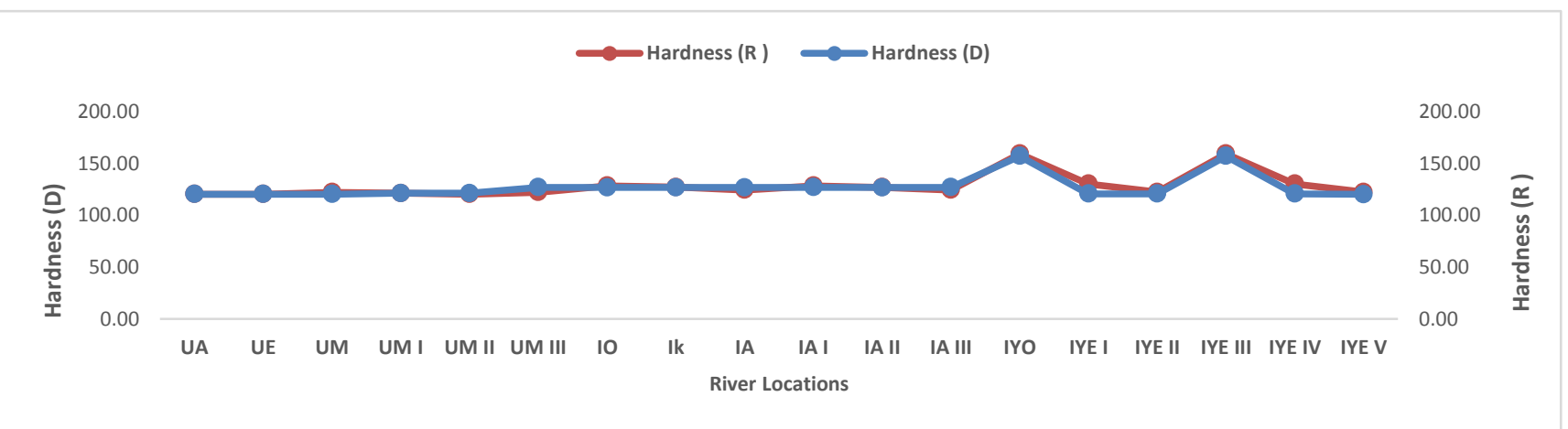

Figure 15: Behavioural pattern of the hardness with respect to time and space.

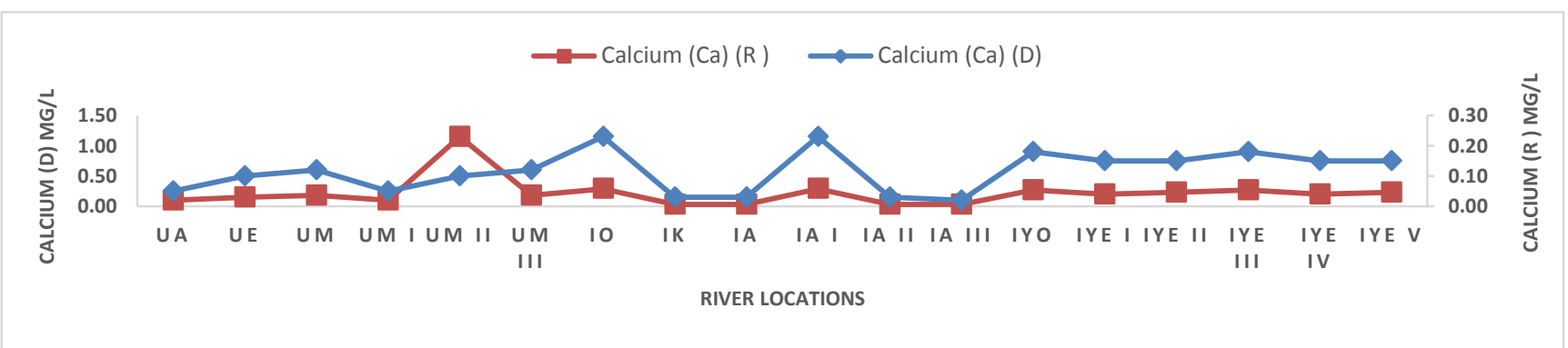

Figure 16: Behavioural pattern of Calcium (Ca) with respect to time and space.

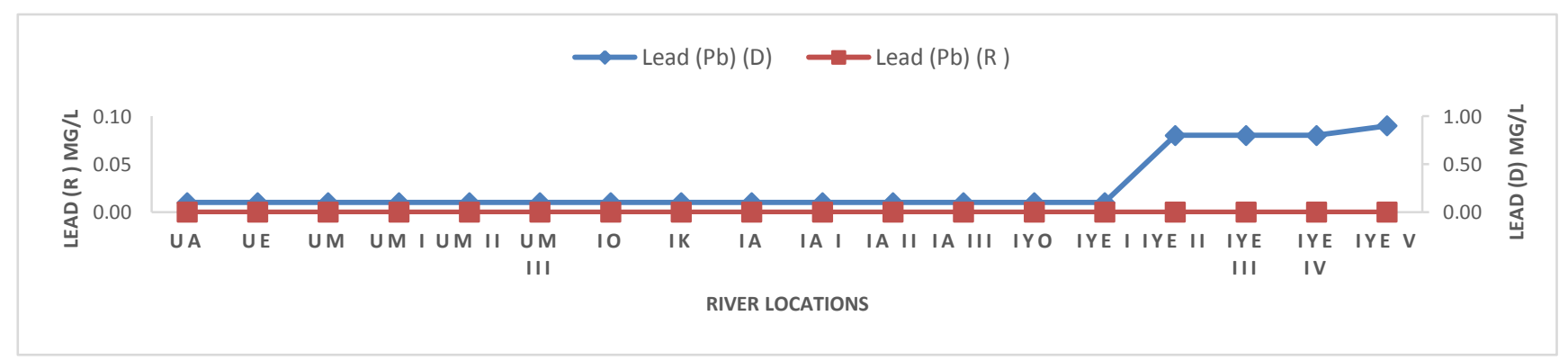

Figure 17: Behavioural pattern of Lead $(\mathrm{Pb})$ with respect to time and space. 


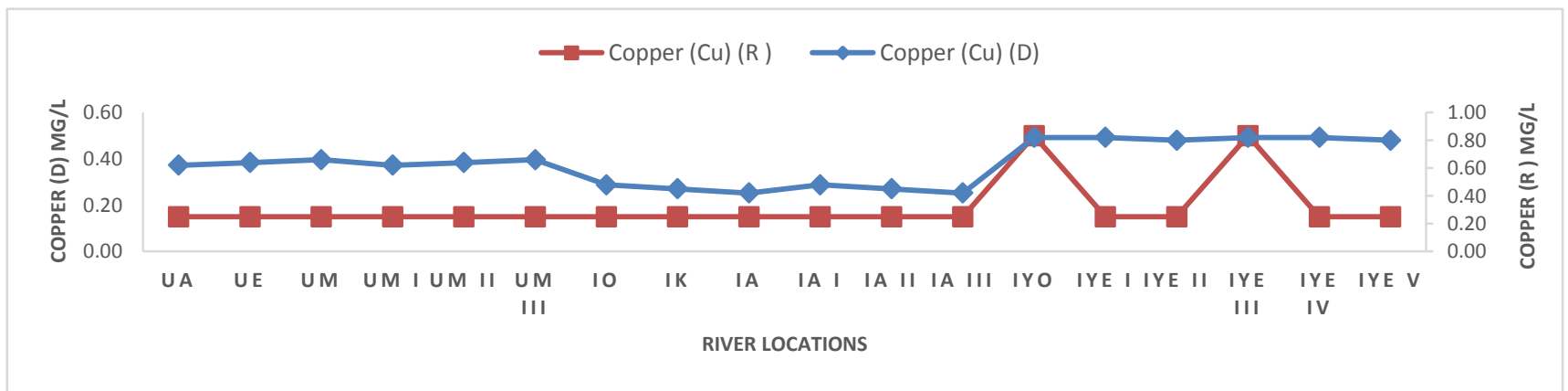

Figure 18: Behavioural pattern of Copper $(\mathrm{Cu})$ with respect to time and space.

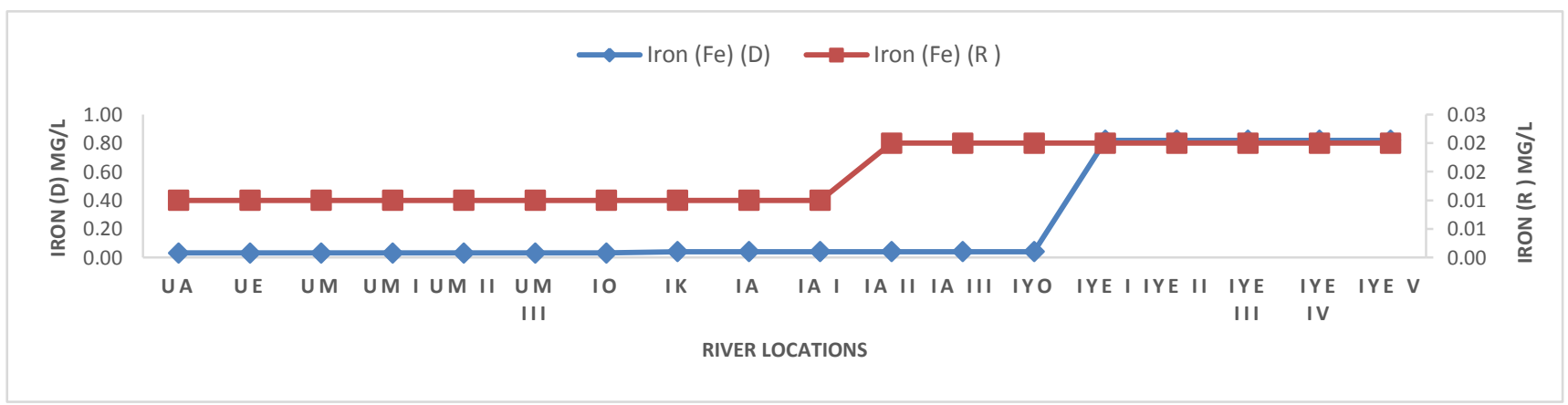

Figure 19: Behavioural pattern of Iron $(\mathrm{Fe})$ with respect to time and space.

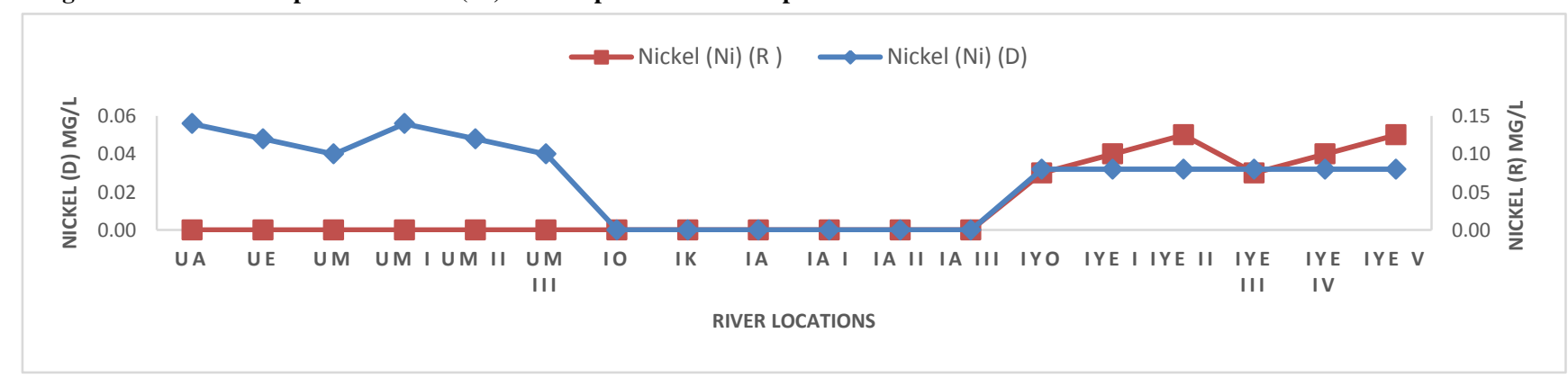

Figure 20: Behavioural pattern of Nickel (Ni) with respect to time and space.

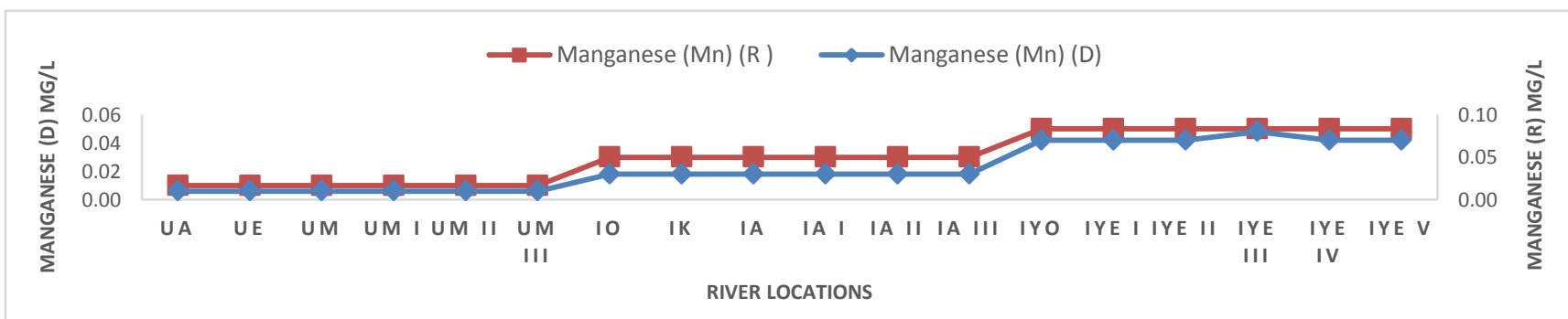

Figure 21: Behavioural pattern of Manganese (Mn) with respect to time and space.

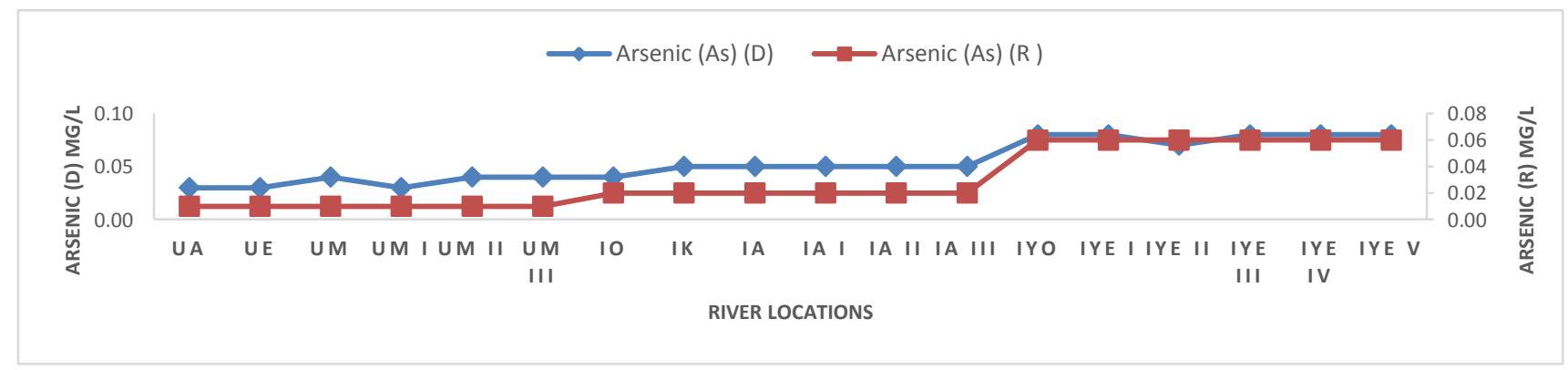

Figure 22: Behavioural pattern of Arsenic with respect to time and space. 


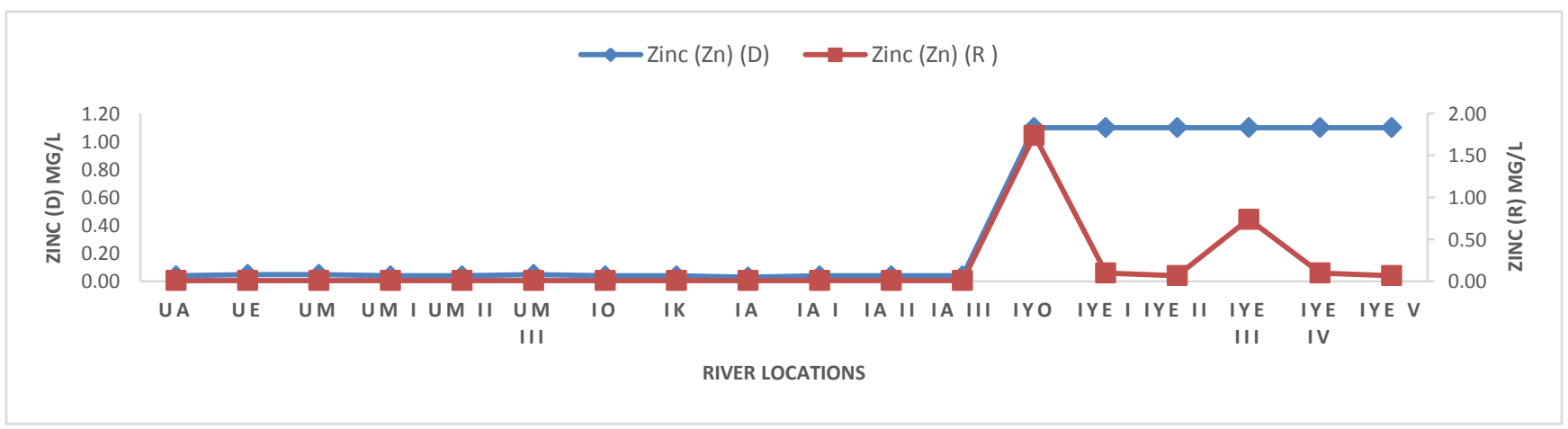

Figure 23: Behavioural pattern of Zinc (Zn) with respect to time and space.

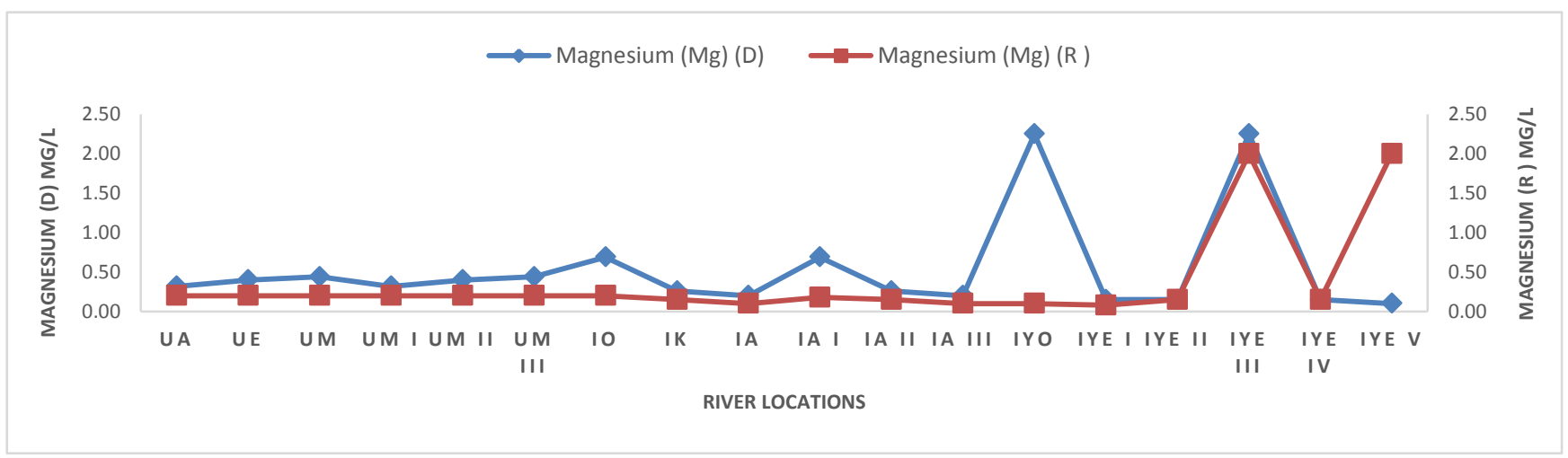

Figure 24: Behavioural pattern of Magnesium (Mg) with respect to time and space.

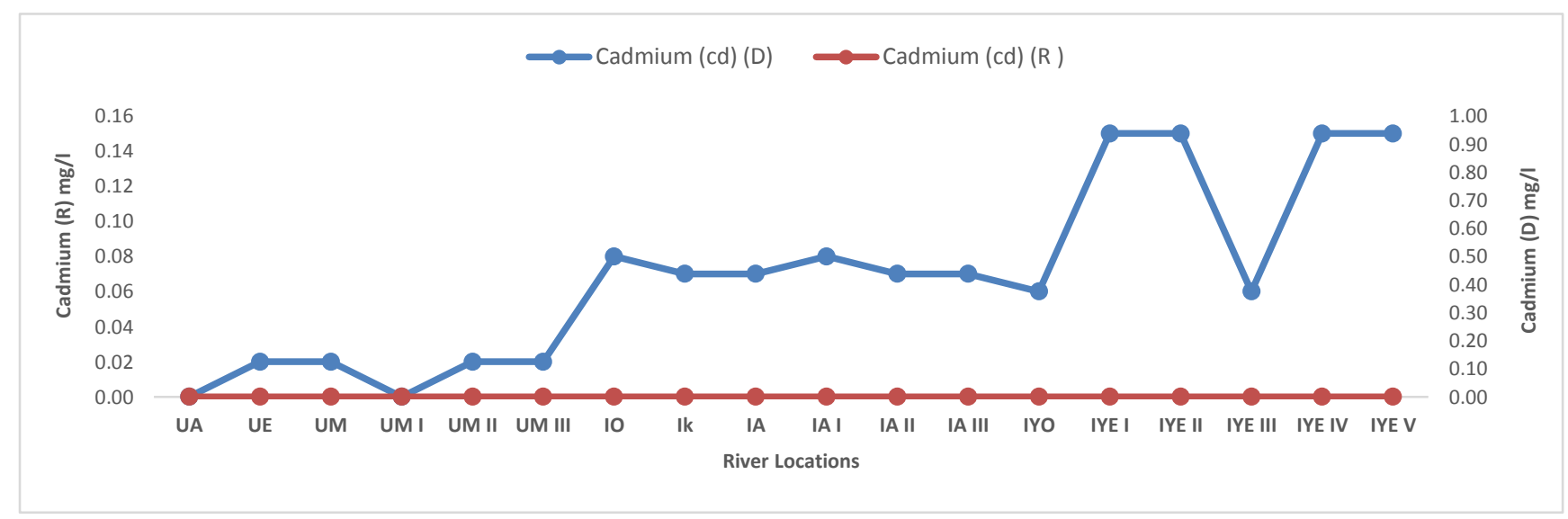

Figure 25: Behavioural pattern of Cadmium (Cd) with respect to time and space.

Table 1: Legend for Figures 1 - 25.

\begin{tabular}{lclclc}
\hline \multicolumn{1}{c}{ River Location } & Abbreviation & River Location & Abbreviation & River Location & Abbreviation \\
\hline Ubei Amaiyi & UA & Idima Oko & IO & Iyioka okwukwo & IYO \\
Ubei Etiti & UE & Idima Okporojo & IK & Iyioka Extension I & IYE I \\
Ubei Amangwu & UM & Idima Amaiyi & IA & Iyioka Extension II & IYE II \\
Ubei Amangwu I & UM I & Idima Amaiyi I & IA I & Iyioka Extension III & IYE III \\
Ubei Amangwu II & UM II & Idima Amaiyi II & IA II & Iyioka Extension IV & IYE IV \\
Ubei Amangwu III & UM III & Idima Amaiyi III & IA III & Iyioka Extension V & IYE V \\
\hline
\end{tabular}


APPENDIX 2

Table 2: Summary of tested ANOVA results.

\begin{tabular}{|c|c|c|c|c|c|c|c|c|c|c|c|c|c|c|}
\hline \multicolumn{5}{|c|}{ WITH RESPECT TO TIME (SEASON ) } & \multicolumn{5}{|c|}{ WITH RESPECT TO SPACE (DURING DRY SEASON) } & \multicolumn{5}{|c|}{ WITH RESPECT TO SPACE (DURING RAINY SEASON) } \\
\hline Parameter & $\begin{array}{c}\text { F- } \\
\text { CAL }\end{array}$ & $\begin{array}{c}\text { F- } \\
\text { TA } \\
\text { B }\end{array}$ & $\begin{array}{c}\text { Level } \\
\text { of } \\
\text { Signt }\end{array}$ & Decision & Parameter & $\begin{array}{c}\text { F- } \\
\text { CAL }\end{array}$ & $\begin{array}{c}\text { F- } \\
\text { TAB }\end{array}$ & $\begin{array}{c}\text { Level } \\
\text { of } \\
\text { Signt }\end{array}$ & Decision & Parameter & $\begin{array}{c}\text { F- } \\
\text { CAL }\end{array}$ & $\begin{array}{c}\text { F- } \\
\text { TAB }\end{array}$ & $\begin{array}{c}\text { Level of } \\
\text { Signt }\end{array}$ & $\begin{array}{c}\text { Decisio } \\
\mathbf{n}\end{array}$ \\
\hline $\mathrm{pH}$ & 0.53 & 4.6 & NS & Accept & $\mathrm{pH}$ & 0.535 & 5.76 & NS & Accept & $\mathrm{pH}$ & 0.535 & 5.76 & NS & Accept \\
\hline $\begin{array}{c}\text { Total } \\
\text { Dissolved }\end{array}$ & 0.08 & 4.6 & NS & Accept & $\begin{array}{c}\text { Total } \\
\text { Dissolved }\end{array}$ & 2.565 & 5.76 & NS & Accept & $\begin{array}{c}\text { Total } \\
\text { Dissolved }\end{array}$ & 1.268 & 5.76 & NS & Accept \\
\hline Salinity $\%$ & 23.915 & 5.76 & NS & Accept & Salinity $\%$ & $\begin{array}{c}23.91 \\
5\end{array}$ & 5.76 & NS & Accept & Salinity $\%$ & 0.969 & 5.76 & NS & Accept \\
\hline $\begin{array}{c}\text { Electrical } \\
\text { Conductivity }\end{array}$ & 0.91 & 4.54 & NS & Accept & $\begin{array}{c}\text { Electrical } \\
\text { Conductivity }\end{array}$ & 1.409 & 5.76 & NS & Accept & $\begin{array}{c}\text { Electrical } \\
\text { Conductivity }\end{array}$ & 2.13 & 5.76 & NS & Accept \\
\hline Temperature & 0.483 & 4.54 & NS & Accept & Temperature & 0.439 & 5.76 & NS & Accept & Temperature & 1.418 & 5.76 & NS & Accept \\
\hline $\begin{array}{c}\text { Total } \\
\text { Suspended }\end{array}$ & 1.674 & 4.54 & NS & Accept & $\begin{array}{c}\text { Total } \\
\text { Suspended }\end{array}$ & 0.827 & 5.76 & NS & Accept & $\begin{array}{c}\text { Total } \\
\text { Suspended }\end{array}$ & 1.048 & 5.76 & NS & Accept \\
\hline $\begin{array}{c}\text { Total } \\
\text { Solid(TS) }\end{array}$ & 1.459 & 4.54 & NS & Accept & $\begin{array}{c}\text { Total } \\
\text { Solid(TS) }\end{array}$ & 1.874 & 5.76 & NS & Accept & $\begin{array}{c}\text { Total } \\
\text { Solid(TS) }\end{array}$ & 1.531 & 5.76 & NS & Accept \\
\hline Turbidity & 0.196 & 4.54 & NS & Accept & Turbidity & 1.47 & 5.76 & NS & Accept & Turbidity & 1.032 & 5.76 & NS & Accept \\
\hline $\begin{array}{l}\text { Nitrate } \\
\text { (NO3) }\end{array}$ & 0.004 & 4.54 & NS & Accept & $\begin{array}{l}\text { Nitrate } \\
\text { (NO3) }\end{array}$ & 0.805 & 5.76 & NS & Accept & $\begin{array}{l}\text { Nitrate } \\
\text { (NO3) }\end{array}$ & 0.906 & 5.76 & NS & Accept \\
\hline $\begin{array}{c}\text { Carbonate } \\
\text { (NO3) }\end{array}$ & 0.052 & 4.54 & NS & Accept & $\begin{array}{c}\text { Carbonate } \\
\text { (NO3) }\end{array}$ & 1.971 & 5.76 & NS & Accept & $\begin{array}{c}\text { Carbonate } \\
\text { (NO3) }\end{array}$ & 1.72 & 5.76 & NS & Accept \\
\hline $\begin{array}{l}\text { Sulphate } \\
\text { (SO4) }\end{array}$ & 5.609 & 4.54 & NS & Accept & $\begin{array}{l}\text { Sulphate } \\
\text { (SO4) }\end{array}$ & $\begin{array}{c}- \\
8.933\end{array}$ & 5.76 & $1 \%$ & Reject & $\begin{array}{l}\text { Sulphate } \\
\text { (SO4) }\end{array}$ & $\begin{array}{c}21.91 \\
5\end{array}$ & 5.76 & $1 \%$ & Reject \\
\hline $\begin{array}{l}\text { Phosphate } \\
\text { (PO4) }\end{array}$ & 0.077 & 4.54 & $5 \%$ & Reject & $\begin{array}{l}\text { Phosphate } \\
\text { (PO4) }\end{array}$ & 1.293 & 5.76 & NS & Accept & $\begin{array}{c}\text { Phosphate } \\
\text { (PO4) }\end{array}$ & 2.024 & 5.76 & NS & Accept \\
\hline $\begin{array}{c}\text { Dissolved } \\
\text { Oxygen }\end{array}$ & 0.12 & 4.54 & $1 \%$ & Reject & $\begin{array}{l}\text { Dissolved } \\
\text { Oxygen }\end{array}$ & 0.564 & 5.76 & NS & Accept & $\begin{array}{l}\text { Dissolved } \\
\text { Oxygen }\end{array}$ & 0.096 & 5.76 & NS & Accept \\
\hline $\begin{array}{l}\text { Chemical } \\
\text { Oxygen }\end{array}$ & 8.692 & 4.54 & $1 \%$ & Reject & $\begin{array}{c}\text { Chemical } \\
\text { Oxygen }\end{array}$ & 7.34 & 5.76 & $5 \%$ & Reject & $\begin{array}{l}\text { Chemical } \\
\text { Oxygen }\end{array}$ & 5.82 & 5.76 & $5 \%$ & Reject \\
\hline Hardness & 0.064 & 4.54 & NS & Accept & Hardness & 0.72 & 5.76 & NS & Accept & Hardness & 1.614 & 5.76 & NS & Accept \\
\hline Calcium (Ca) & 1.536 & 4.54 & NS & Accept & Calcium $(\mathrm{Ca})$ & 0.9 & 5.76 & NS & Accept & Calcium $(\mathrm{Ca})$ & 1.324 & 5.76 & NS & Accept \\
\hline Lead $(\mathrm{Pb})$ & 1.554 & 4.54 & NS & Accept & Lead $(\mathrm{Pb})$ & 1.532 & 5.76 & NS & Accept & Lead $(\mathrm{Pb})$ & 0 & 5.76 & NS & Accept \\
\hline Copper $(\mathrm{Cu})$ & 21.122 & 4.54 & $1 \%$ & Reject & Copper $(\mathrm{Cu})$ & 0.455 & 5.76 & NS & Reject & Copper $(\mathrm{Cu})$ & 1.229 & 5.76 & NS & Accept \\
\hline Iron $(\mathrm{Fe})$ & 4.652 & 4.54 & $5 \%$ & Reject & Iron $(\mathrm{Fe})$ & 0 & 5.76 & NS & Reject & Iron $(\mathrm{Fe})$ & 0 & 5.76 & NS & Accept \\
\hline Nickel (Ni) & 7.699 & 4.54 & $5 \%$ & Reject & Nickel (Ni) & 84 & 5.76 & $1 \%$ & Reject & Nickel (Ni) & 48 & 5.76 & $1 \%$ & Accept \\
\hline $\begin{array}{l}\text { Manganese } \\
(\mathrm{Mn})\end{array}$ & 0.497 & 4.54 & NS & Accept & $\begin{array}{l}\text { Manganese } \\
\text { (Mn) }\end{array}$ & 283 & 5.76 & $1 \%$ & Reject & $\begin{array}{l}\text { Manganese } \\
(\mathrm{Mn})\end{array}$ & 0 & 5.76 & $1 \%$ & Accept \\
\hline Arsenic (As) & 6.511 & 4.54 & NS & Accept & Arsenic (As) & 133 & 5.76 & $1 \%$ & Reject & Arsenic (As) & 0 & 5.76 & $1 \%$ & Accept \\
\hline Zinc (Zn) & 2.215 & 4.54 & NS & Accept & Zinc (Zn) & 1.492 & 5.76 & $1 \%$ & Reject & Zinc (Zn) & 1.802 & 5.76 & $1 \%$ & Accept \\
\hline $\begin{array}{l}\text { Magnesium } \\
(\mathrm{Mg})\end{array}$ & 0.33 & 4.54 & NS & Accept & $\begin{array}{l}\text { Magnesium } \\
(\mathrm{Mg})\end{array}$ & 0.404 & 5.76 & NS & Accept & $\begin{array}{l}\text { Magnesium } \\
(\mathrm{Mg})\end{array}$ & 0.82 & 5.76 & NS & Accept \\
\hline $\begin{array}{l}\text { Cadmium } \\
\text { (cd) }\end{array}$ & 16 & 4.54 & $1 \%$ & Reject & $\begin{array}{l}\text { Cadmium } \\
\text { (cd) }\end{array}$ & 0.404 & 5.76 & $5 \%$ & Reject & $\begin{array}{l}\text { Cadmium } \\
\text { (cd) }\end{array}$ & 9.5 & 5.76 & $5 \%$ & Accept \\
\hline Bacteria & 12.915 & 4.54 & $1 \%$ & Reject & Bacteria & 1.107 & 5.76 & $1 \%$ & Reject & Bacteria & 0.653 & 5.76 & $1 \%$ & Reject \\
\hline Fungi & 0.513 & 4.54 & NS & Accept & Fungi & 2.68 & 5.76 & NS & Accept & Fungi & 2.68 & 5.76 & NS & Accept \\
\hline
\end{tabular}

